\title{
From the History of Formation Uzbek Oral-Professional Music
}

\author{
Elnora Mamadjanova \\ State conservatory of Uzbekistan, Tashkent, Uzbekistan
}

\begin{abstract}
First features of formation of oral-professional genres in the territory of Uzbekistan were known from ancient time. Examples of preserving wall painting, small statues with musicians images evidence that professionalism was taken place in the early of 1st millennium. Dastan, Katta Ashula, Makom are the main oral-professional genres of the Uzbeks. History facts are in the paper.

Keywords: oral, professional, genre, Dastan, Katta Ashula, Makom, feature, ustoz-shogird, music instruments, dombra, kobuz, Avesta, Barbad, Farabi, Ibn-Sina
\end{abstract}

\section{Introduction}

The main layer of the musical heritage of the Uzbek people is oral-professional art. Surviving sources suggest the beginnings of professionalism in the region during the Zaroastrizm time when sections of the holy book Avesta-gatas sung by priests, who held certain skills. In order to find formation about the existence of syncretic forms of art functioning religious purposes long before the first millennium A.D., indicated the existence of elements of professionalism, particularly in the possession of playing musical instruments, enough to refer to the material culture of the Central Asian region.

The famous Ayrtamsky frieze was found during excavations of the ancient city Airtam near the town of Termez, abas-relief depicting five musicians with instruments in their hands-harp, lute, aulos, drums, and cymbals. Where would be a picture of the whole ensemble of musicians, if it was not true and it would be only an object of imagination of the sculptor? Researchers attribute the appearance of the frieze with the spread of Buddhism in the Kushan Empire in Uzbekistan territory and belong to the I-II centuries A.D. Of course, the existence of a rich tool in the early of the first millennium may indicate a system of gaining skills of performance (Vizgo, 1980).

\begin{abstract}
A Little Bit History
It can be concluded that in that period began to form the concept of musical expertise on the extant sources, shown that was the musical culture of VI-VII centuries on the territory of Uzbekistan. Music was not longer a part of the cult genres and acquired the status of an independent form of expression and an art form. However, it was in that period assimilation and enrichment of the folklore features of different peoples of the region, and as a result, the impact on the emergence of a more complex genres formation as oral-professional music. Thus, the origins of the genre, as Katta Ashula, traced during the given period. Renowned musician, singer, performer Barbad, whose name is associated with the beginning of the first author writing in the Central Asian region, left examples of the work, some of whom were the first software product in the history of musical creativity.
\end{abstract}

Elnora Mamadjanova, Lecturer of Department of History of Music, State Conservatory of Uzbekistan. 
Subsequent, no less significant period in the history of Uzbekistan was a turning point. Planting of Islam, endless internecine wars between the ruling dynasties influenced the cultural development of the region by strengthening its commitment to preserve the traditions and identity. The IX-X-th centuries in the history of the Uzbek people was considered to be the most fruitful period in the development of the sciences, with the establishment of such scientists encyclopedic treatises as Farabi, Ibn Sina, al-Biruni, etc. They not only codified achievements of previous centuries and created the foundation for the science of music, but also provided valuable information on the state of music of their era.

Next generation's scientists have continued to develop musical science and created many important works, including “The Book of Circles” by Safiuddin Urmavi (XIII), which laid the scientific foundations of makomat, treatises on music Abdurrahman Djami (XV), Dervis Ali Changi (XVI-XVII), containing valuable information about the origin of music, especially the modal system, rhythm, musical instruments, as well as the known artists of his era. It was a period of XV-XVII-th centuries linked the emergence of makomat, its theoretical basis, which after a short time in the middle of the XVIII-th century became the basis of the formation of the main genres of orally-professional music-makom and its major cycles.

\section{Main Genres}

The concept of "orally-professional art" contains the phenomenon of a special system of "ustoz-shogird" ("teacher-student”), which was distributed in the Central Asian region. On Uzbek territory it began to take shape with the advent of the origins of musical professionalism and especially fruitful role played in the development of makom cycles. Feature of this system was, above all, in unquestioning obedience to the creator, the student teacher, who carried out a careful selection of the best students. They're passing a long learning process, which takes between 10-15 years old, "sift", only the most talented could reach the end of the education. And they, having acquired professional skills, could be not only performers, interpreters, also opened own school and entered their teaching methods as well.

The school could learn only males, and feature was the fact that young boys were not allowed to leave the walls of the school during the learning process. With no musical notation, memorizing by ear a lot of musical patterns, growing up in front of the teacher, the student often became upscale executive interpreter.

In the XX-th century, when were made the records of makom cycles and other genres of Uzbek heritage, such system of education began to give way to academic: Student trained in special designated days and hours, and were able to live at home. Perhaps there was no need to compare the two systems, while the almost complete disappearance of the first was already yielding results. Fades the relationship between the basic functions of the musician-performer, the interpreter, but this was reduced and the learning process, five to eight years, slowly disappearing the relationship between the basic functions of the musician-performer, interpreter, in addition reduced and the process of learning to five to eight years.

In Uzbek musical heritage, there are so-called border genres in which the line between folk and oral-professional creativity is subtle. However, they can not be attributed to folklore. One of these genres-Dastan that incorporated music and poetry of the people, the starting point of its formation was laid long before the I-st millennium. Dastan genre is prevalent in such parts of Uzbekistan, whose population was engaged in agriculture and animal husbandry. This steppe region of the country includes Surkhandarya and Kashkadarya, where are special conditions with very hot climate in summer and more gentle in winter, and Khorezm region. 
Boundless spaces favorable to livestock, contributed to the emergence of special way of life of the people, when development of some land and grazing, did not mean the settlement, on the contrary, gave impetus to a free life, independent of the more or less favorable conditions. The appearance of a special kind of performers — people with "prepared" skills in another word, pasted a certain period of training—bakhshi or dastanchi-folk musicians, storytellers, indicated that in that period there were sources of professional creativity.

Dastan content was the most diverse-from the more simple songs, consisting of three to four stanzas to entire poems, including several stories in the main complex in the seven to eight meters. Music, of course, played a big role in Dastan. Simple at first glance, accompanied mainly by kobuz, dombra (in Surkhandarya, Kashkadarya region) or dutar, rubab (in Khorezm) was mainly for rhythmic stabilization or intermediate inserts between chapters. But if you imagine a recitative singing of Bakhshi without musical accompaniment, immediately disappears unique flavor of this genre. Low husky voice of Bakhshi, selflessly devoted all its possibilities, holding a tool, like to draw strength and energy from him, tells of the "affairs of by gone days", legends, historical events, the exploits of heroes. Musical instrument for him is the expression of the national spirit and character of the people, as well as his own contribution to the development of traditions.

Heroes of dastan-historical figures, heroes, liberators (Alpamysh, Ger-oglu), are members of the ruling dynasties (Queen Tomiris). Dastan genre was the starting point for the formation of common and popular in many nations of the Central Asian region poetic genre of the poem, consisting of five to seven stories-“Hamsa". It won a special love for the people of tales of immortal love "Laylo and Majnun", "Farhad and Shirin", and many others.

Dastan feature is recitative style of singing, which development is not regulated by a specific form. All depends on the story, which is the basis of the dastan. As a rule, it lasts from a few minutes to an hour. The range of tunes fits in octave and goes beyond it only in the culmination, which is rare, in contrast to other vocal genres of Uzbek music. Rhythmic of Dastans is very unpretentious, more stable and generally supports the poetic text. A feature of Dastan is the alternation of music and poetic text. It depends on the professional skill of the performer. Often you can hear the brilliance perfect tooling of Bakhshi.

If the Surkhandarya-Kashkadarya region extended the execution of Dastan by the accompaniment of dombra and kobuz, in Khorezm Bakhshi may accompanied himself by an ensemble of performers on dutar, gidjak, and bulaman. Naturally this makes Khorezm epics more saturated in the musical design. In Khorezm in the early of XX-th century, was born the tradition of female execution of dastan, called Halfa. That was a significant event in the Uzbek musical culture, because of the special mentality that women did not have the rights and opportunities of manifestation of their talent, especially in the open action. So, many genres of folklore had analogue of the female execution, the so-called shape ichkari (“inner room”).

\section{Conclusion}

The modern approach to the execution of Dastan in Uzbekistan emerged in recent decades. Transforming it into a bright concert item leveled some of its features, added new ones. Of course, disappeared the sound intimacy, decreased improvisation, thus manifested a greater emphasis on the musical side. At the same time preserved the sharpness of rhythm, increased dynamics, the most colorful special voice capabilities (with alternating low hoarse voice to simulate the animals). In addition, many modern groups of execution entered Dastan's dancers. In general, the Dastan genre is one of the oldest and at the same time retains the features and 
gives impetus to further existence in the future.

\section{References}

Vizgo, T. (1980). Music instruments of Middle Asia. Moscow: Music.

Merriam, A. (1964). The anthropology of music. Evanston: Northwestern University Press.

Mamadjanova, E. (July 2011). Uzbek makoms in the XXI-st century. Journal of Literature and Art Studies, 1(1), 31-36. Libertyville, USA: David Publishing Company.

Mamadjanova, E. (2011). The role of Uzbekistan in the process of East countries interaction. IMACO International Conference. Nettl, B. (1964). The study of Ethnomusicology.

Ibragimov, O. (2006). Fergana-Tashkent makoms. Tashkent: Music. 